\title{
RÉMY OLLIER AND IMPERIAL CITIZENSHIP
}

\section{Zaki Nababoo}

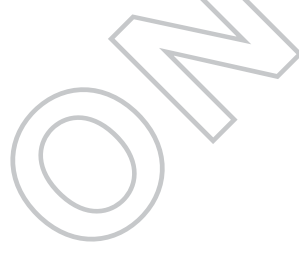

Faculty of Arts and Humanities, Liverpool Hope University, UK

This essay discusses Rémy Ollier's (1816-45) journalism. As an early claimant of citizenship through (rather than against) the British Empire during the 1840 s, Ollier attempted to redress a gap that he perceived between the institutionalization of rights in Britain and Mauritius. Established accounts of Ollier's political intervention provide a rich narrative of how his efforts indentured labour are implicated in the development of rights in Mauritius and broader

Mauritius

Ollier

Rémy

subaltern postcolonial nationalisms. However, I argue that facets of his expression of imperial citizenship reside apart from this genealogy. To explore how Ollier uniquely created imperial citizenship, an "acts"-influenced approach to citizenship is adopted. By analyzing his writings in La Sentinelle de Maurice, I reveal how imperial citizenship is generated through a subversive loyalism to Britain and an orientalist portrayal of indentured labourers. I conclude by mobilizing Ollier's struggle as a challenge to the notion that citizenship realizes itself in teleological fashion.

\section{Introduction}

Rémy Ollier (1816-45) occupies an increasingly central place in the Mauritian national imaginary. He is remembered for founding La Sentinelle de Maurice: journal politique, commercial, et littéraire in 1843. Between 1843 
and 1844 Ollier wrote prolifically for the newspaper with the aim of pressurizing the legislative council in Mauritius, and the government in Britain, to grant rights to the island's gens de couleur. Almost a hundred years after his birth, Ollier was memorialized in the Company Gardens of Port Louis. The bronze bust that was unveiled in 1916 rests peacefully amongst the same banyan trees to this day.

As Fanon $(2004,15)$ reminds us, the "world of statues" in the colonial theatre physically reflected the immobilization of the colonized in history. The presence of colonial statues marked the absence of the colonized as makers of history; silent witnesses to a past and present made in, and for, the name of Europeans. These concentrated and consecrated testaments of imperial alienation acted as a disciplinary gaze upon colonized subjects, symbolically reaffirming imperial authority. During the twentieth century, nationalist movements against British imperialism became an exclusive prism for framing colonized movement in history. This symbolically manifested in postcolonial resistance with the physical uprooting of imperial statues from their seemingly eternal foundations. It might appear obvious why the bust of Ollier has not succumbed to this fate in post-independence Mauritius. He currently enjoys a largely untarnished reputation as a colonized anti-racist activist (Fokeer 1917; Harmon 2015). Yet the fact that he was memorialized during British rule hints at a more complex, at times supportive, relationship with colonial authority.

This essay explores the paradoxes and contradictions within Ollier's interventions. It moves beyond dominant memorializations of Ollier, and the historicism upon which they depend, by exposing how he enacted citizenship under conditions of its formal absence. To capture how Ollier's demands for imperial reform engendered new ways of enacting citizenship, I argue that we need to move away from existing narratives of his struggle that implicitly cast his activism through relationships of subalternity and citizenship as transitional in terms of status. His activism needs to be understood apart from stymied lines of exclusion to formal inclusion.

By adapting Engin Isin's (2012, 109-11) exploration of acting "as if” one were a citizen we can gain a new insight into how Ollier's campaign exhibited citizenship as political subjectivity. This frame of interpretation offers one avenue for uncovering how political representation was enacted without authorization or recognition in juridical and legislative spheres. In particular, I trace how Ollier generated one of the first conceptions of a public in Mauritius along multiracial lines. I argue that his demographic ascriptions were integral to his demand for independence from racial hierarchies. Race surfaced as both an insignificant marker of difference and a prism for constituting a rightful people. However, his manner of dissolving the dividing lines between British and colonial subjects also harboured orientalist representations of recent migrants. 
Canvassing Ollier's multi-layered expression of imperial citizenship affirmations of imperial belonging, pleas for imperial reform, and an ambivalent stance towards colonial racialization - allows for his memorialization to be cast anew. Imperial fealty and racialism are shown to occupy a central place in his enactment of citizenship. The significance of this is not confined to the past. I conclude by mobilizing aspects of his struggle to further denaturalize the notion that citizenship singularly and progressively unfolds.

\section{From the itinerary of the subject to citizenship as political subjectivity}

Ollier was born on 6 October 1816 in Grand Port, Mauritius. He received a private schooling in his early years. However, this ended when his father, Benoit Ollier, died in 1832. Without the clout and capital of the former French artillery officer, his mother Julie Guillemeau (a daughter of a slave) encouraged the young Ollier to become a harness-maker's apprentice (Wesley 1921, 56). After he experienced the "humiliation" and "drudgery" faced by the artisan class, Ollier became committed to ameliorating the condition of the oppressed (Mulloo 1968, 28). During the late 1830s this took the form of teaching in Petite Rivière and through a school he established in Port Louis with the help of his wife, Louise Adrienne Ferret (Napal 1984, 61). These attempts were largely unsuccessful and by the early 1840s his attention drifted towards journalism.

To understand the sphere that Ollier began to enter, it is worthwhile first to highlight how the relationship between the French and the British was reflected in (and strengthened by) the press. After the transfer of Isle de France to the British in 1810, rifts deepened between the British colonial administration and the French elite as planters' treatment of slaves contradicted policies of slave punishment (Report on the Slave Trade 1828). In the wake of colonial and slave rebellions, increased costs of slavery, and philanthropic pressure, gradualism gave way to forthright abolitionism (Barker 1996; Green 1991). A Legislative Council of Mauritius report pointed to "the dangers of emancipation," warning government that loss of life and property would ensue (Colville 1830). In 1832 the wealthy French planter Adrien d'Épinay established Le Cernéen to reverse the looming "threat" of abolition (Salverda 2015, 40). This newspaper became an explicit mouthpiece for the grievances of French planters and merchants. Although d'Épinay's lobbying ultimately failed, his efforts furthered the cause for post-abolition compensation (Macmillan 2000, 326-27). French settlers also came to acquire more formal channels for influencing colonial policy. The 1830s saw the cementing of an "Anglo-French alliance" through greater representation in 
the Council of Government (Mulloo 2007, 192). This “advise and assist” legislature (Mathur 1991, 13) was a vital pillar for advocating reform in the nascent plantocracy.

Ollier was concerned that the monopoly Le Cernéen and Le Mauricien held over the press led to only a partial representation of grievances in Mauritius (Benoit 1995). This became a catalyst for Ollier's shift away from formal pedagogy and towards journalism. More specifically, it was after reading a racist review of Alexandre Dumas' Antony published in Le Mauricien that his interest in the press grew (Wesley 1921, 59). The reviewer claimed the play's approach to marriage was contaminating the morals of Mauritian society and was a reflection of Dumas' heritage (Fokeer 1917, 17-19). Edward Baker (a friend of Ollier who would later become a patron of La Sentinelle de Maurice) wrote a riposte to the article, yet both Le Mauricien and Le Cernéen refused publication (Napal 1984,61 ). Aside from being incensed at Le Mauricien for disseminating a review that called for censorship, the lack of alternative outlets demonstrated to Ollier how the press operated as gatekeeper of public and political opinion (Fokeer 1917, 17-19). As Ollier was drawn towards journalism, what prepared him for entry was participation in the Société d'Émulation Intellectuelle (est. 1839). This was the first "mulatto" literary society in Mauritius (Furlong 2005, 33). The aim of the society was to cultivate progressive poets, artists, and authors; education was situated as a defense against prejudice, a view that Ollier carried with

1 Further research is needed to clarify Ollier's involvement with the Sociéte d'Émulation Intellectuelle; there is a lack of source material detailing his precise output from the literary society. Addressing this is beyond the scope of this essay, which primarily focuses on Ollier's writings for La Sentinelle.

2 The circumstances of his death are still debated and there are rumors he was poisoned (Harmon 2015).

3 Translations from French sources to English are mine. Original phrasing is him through his journalism (Furlong 2005, 34). ${ }^{1}$

Ollier helped found La Sentinelle de Maurice in April 1843 as a weekly response to the denigration of non-white populations (Raynal 1995). After he purchased the printing press of the defunct newspaper La Balance in October 1843, circulation increased to three times a week (Wesley 1921, 61). La Sentinelle set itself the task of promoting the application of a universal civil treatment by authorities and an extension of the limited colonial franchise to non-whites. This came at great personal cost. Ollier endured slander from elements of the Mauritian press, a lawsuit, and an assault that nearly took his life. Yet what brought his campaign to a swift end was a fatal inflammation of the intestines (Wesley 1921, 65). ${ }^{2}$ Ollier died on 26 January 1845 . His funeral ceremony took place three days later. According to Cabon $(1963,159)$, it was attended by those who came to pay a "final homage to a man who had so well embodied the aspirations of the coloured population." ${ }^{3}$ Edward Baker capitalized on the demographic cross-section of attendees by stating that it illustrated the success of La Sentinelle in uniting the coloured classes (Fokeer 1917, 47).

Ollier never formally acquired the rights he tirelessly strove for. Nevertheless, his activism was said to have influenced subsequent civil reforms such as the promotion of a free press (Martial 1995), scholarships for disadvantaged populations to attend the Collège Royal, lines of credit for merchants other 
retained where possible. than Franco-Mauritians (Prosper 1995), and constitutional reforms that laid the basis for the municipality of Port Louis after 1850 (Bijoux 1917). His clamour for colonized political representation on the Council of Government is deemed to have facilitated the appointment of Hippolyte Lemière in 1856 (its first créole member) (Teelock 2001, 330). The Truth and Justice Commission of Mauritius (2011, 248-49) placed Ollier as a notable voice of the gens de couleur, a relatively affluent social group that made a decisive impact on the institutions and scope of representative politics in nineteenth-century Mauritius.

With these purported effects on Mauritius, it is unsurprising that Ollier has been situated within a broader postcolonial narrative. His pedagogical emphasis is likened to an approach favoured by Booker T. Washington and Jose Rizal Mercado (Fokeer 1917, 56). Basdeo Bissoondoyal, a prominent spiritual and political leader in mid-twentieth-century Mauritius whose tactics were informed by anticolonial counterparts in India, emphatically praised Ollier as a "Ghandiate before Gandhi" (1968, 89). Mulloo (1968, 29 ) is less exuberant about Ollier's politics, noting his refusal to embrace indentured labourers as "sons of Mauritius." Yet Mulloo also weaves his life and work into the exigencies of anticolonial concerns. Mulloo's Footprints (1968), published during the year of Mauritian independence, calls for a nationalism that is inclusive of all Mauritians and free from pernicious colonial inheritances, such as the suppression of composite cultural identifications and languages. Rémy Ollier is positioned as one marginal footprint in this journey, a trace of a Mauritian past whose trajectory can be mapped within a long road to postcolonial independence. Shared across these interpretations of Ollier's life and politics is the attempt to recover subjugated histories of Mauritius. These histories work to decentre French planters, British administrators, and Indo-Mauritian elites as exclusive agents of change. In this regard, Mauritius is similar to other nations that require serviceable pasts to redefine the aspirations and identifications of a citizenry. I neither seek to evaluate the validity of existing interpretations nor assess its utility for postcolonial narration. Rather, I aim to pay attention to the contextual specificity of Ollier's struggle.

The globalization of the nation-state as a historic frame for witnessing popular sovereignty occludes genealogies of anticolonialism that mobilized decentralized, non-national, and federated visions of political representation within the British Empire (Mantena 2016, 301). To read Ollier as expressing citizenship through this historically compromised backdrop requires a distinctive understanding of citizenship as political subjectivity. This can be worked towards via a discussion of how citizenship is implicated in the overcoming of subalternity.

If we recall, Guha (1982) extended Antonio Gramsci's notion of subalterns - groups who lack access to hegemonic power and therefore the means of 
controlling their representation - to the case of India, where both elite nationalism and British history were underpinned by a liberal historiography that silenced the peasant as constitutive of historical agency. Spivak's essay "Can the Subaltern Speak?" Was a response to this critical intervention in Marxist historiography by, arguably, shifting focus from "what is the true form of the subaltern?" To "how is the subaltern represented?" (Chatterjee 2010, 83). In retrospect, one of its central claims was "if there was no valid institutional background for resistance, it could not be recognized" (Spivak 2010, 228). Even if there were to be institutional recognition of subaltern voice, or the recovery of subjugated knowledge, such a process would have already denied the "irretrievably heterogeneous" colonized through their representation in unified and transparent terms to the researcher (Spivak 1988, 79). Agency surrounds and suffices the subaltern, but it cannot inhere in the subaltern. The subaltern can only be a relational subject position whose "lines of social mobility, being elsewhere, do not permit the formation of a recognizable basis of action" (Spivak 2005, 476). This is instructive for citizenship.

On the one hand, citizenship creates subalternity. The citizen is a relational position by virtue of depending on a constitutive outside: non-citizens. As an alterity-producing device, citizenship is not a priori to the inclusion, exclusion, privilege, and oppression that it generates (Bhambra 2015; Isin 2002). If we view the dynamics of exclusion and inclusion as a contingent element of citizenship discourse, we fail to see how citizenship has historically required these dynamics as its condition of possibility. Citizenship is itself a practice of difference-making that legitimizes the creation of vulnerable populations that can be tortured, killed, segregated, and deported (Bhambra 2015). It allows for groups to emerge that are necessarily left unrepresented.

On the other hand, citizenship denies subalternity. As rights become mobilized in the name of invisible populations, the subaltern is already anticipated as transitory. Citizenship plays a vital role in the identification and interdiction of subjectivity, effacing subalterns by conceptualizing them as marginalized - passive or disenfranchized - active subjects of a civil society (Chatterjee 2004). It is through this anticipated itinerary that subalternity recedes and visibly oppressed groups emerge as struggling for - or being represented as deserving - "access to citizenship (civil society) ... the symbolic circuit for mobilizing subalternity into hegemony" (Spivak 1999, 309). As Pandey $(2010,6-7)$ argues, "the subaltern as potential citizen" is inscribed into universalizing rights claims. Citizenship is therefore an avenue through which subalterns are both constituted and denied by having their consignment as politically inaudible subjects overcome.

Existing accounts of Ollier's politics implicitly cast a narrative of subaltern metamorphosing into (potential) citizen. Since he never acquired the rights he demanded, it would appear that citizenship came after or remained outside of 
Ollier's enterprise. A political subject emerges in history, not a citizen. Yet through the relationships between subalternity and citizenship previously discussed, what has also been suggested is a shift in focus beyond the arduous journey of non-citizen to formal (second-class) citizen. Citizenship not only implies the acquisition of a formal status or participation in an existing civil society. It also emerges at moments where those who lack an officially recognized status constitute new lines of social mobility. To explore this, we require a conceptual shift away from analyzing a struggle for citizenship to citizenship-in-making.

Understandings of citizenship can be pluralized beyond status (defined by juridical inclusions/exclusions) or "habitus" (prescribed spheres of routinized democratic and civic action) by observing citizenship as "political subjectivity" (Isin 2012, 109-11). At stake in this approach to citizenship is neither the issue of how subalterns act as citizens, which returns us to the academically foreclosed task of recovering subaltern agency qua subaltern (Beverley 1999), nor the fabrication of subalterns as "sacrificial" objects, whereby their silence/death/failure becomes another line of resistance against hegemonic modes of representation (Li 2009). Exploring citizenship as political subjectivity enables focus upon (unintentional) enactments of rights that are not formally possessed. Moments of acting "as if" one were a citizen can at times disrupt prescribed, habituated, or tolerated ways of expressing citizenship (Isin 2012, 109-11). For the purpose of this essay, tracking these enactments take place through what Spivak $(2005,483)$ terms "insertion in the public sphere": a claim to citizenship that makes a part (an individual) representative of a whole (a citizenry). This process of displacement, "the right to the metonym/synecdoche political performance of collectivity" (Spivak 2005, 480), can offer a locus for witnessing how conventional ways of representing a citizenry are transgressed. Uncovering Ollier's attempts at standing in for a population, to constitute new definitions of a rightful people, allows for explorations into citizenship as political subjectivity being crafted in the colonial space. The remainder of this essay documents how Ollier enacted citizenship.

\section{Loyalism and multiracialism}

On 8 April 1843 the first edition of La Sentinelle de Maurice: journal politique, commercial, et littéraire left the press alongside The Mauritius Watchman: a weekly newspaper of politics, commerce, and literature. Ollier acted as

4 During Ollier's editorship, feature articles often lacked a editor and columnist for La Sentinelle while Baker assumed these responsibilities for The Watchman (Wesley 1921). ${ }^{4}$ The newspapers were written in French and English, respectively. They varied in content, but feature articles were identical in theme and argument. In addition, the newspapers' formats 
byline. In this essay I primarily draw upon Bijoux's (1910)

collection of Ollier's writings for $L a$ Sentinelle, as it clearly identifies his authorship. Expanding on Bijoux's collection by consulting $\mathrm{La}$ Sentinelle (18431844) held at the National Library of Mauritius archives is beyond the remit of this essay, since it would require a systematic authorship attribution project.

5 As noted from the partial collection of La Sentinelle and The Watchman (AprilMay 1843) held at the British Library. 6 The Watchman did not consistently adopt this motif. were similar: a two/three column layout was predominantly used, with features sometimes lacking a headline. ${ }^{5}$

Prior to arriving at the body text of La Sentinelle, one would encounter the Royal Coat of Arms of the United Kingdom emblazoned under the main title (La Sentinelle de Maurice, 15 April 1843). ${ }^{6}$ The recently devised coat of arms, bearing the motto Dieu et mon Droit, symbolized the newspapers' drive to craft a shared British subjecthood. Coverage of the banking crisis in Mauritius exemplifies one of numerous attempts at framing common status to mean an entwined fate. Both papers emphasized the detrimental effect of the crisis on labourers' wages, planters' loan conditions, and stable credit across the empire - these issues were organized around a theme of failing to meet Britain's expectations of a successful colony (The Mauritius Watchman, 6 May1843; La Sentinelle de Maurice, 6 May 1843). Setting aside the details of the crisis, the editorial decisions foreground two interconnected aspects of Ollier's journalism to be examined further: the courting of British officialdom and the claim to represent a broad population in Mauritius.

The young Ollier was keenly aware that freedom from slavery did not entail a corresponding drive from the British government to usher in substantive political or civil equality (Ollier $1910 \mathrm{~h}$ ). A recurrent theme across his writings was to remedy this situation by reconciling the dominant and the exploited through a common British subjecthood. This guiding principle of Ollier's campaign was set forth in the 21 March 1843 prospectus for La Sentinelle. The mission of the newspaper was to

expose abuses with courage and moderation; right wrongs, encourage merit, in whichever class and under whatever skin it is encountered; to call all Mauritians to a united intelligence - necessary unity, essential to the happiness of mankind and the citizen - without which order disappears to make way for chaos. (Ollier 1910i, 154)

Through his newspaper, Ollier became a prominent voice amongst the gens de couleur. He was instrumental in re-presenting their concerns by giving specificity to the meaning of unity, the authority that could represent a Mauritian community, and the pathways for rights. These entwined concerns and practices gained clarity through a petition, submitted to Queen Victoria in 1843. This was written in English by Edward Baker, though it largely followed the principles of the newspaper outlined by Ollier (Bijoux 1910, 159). The petition stated that since the "coloured classes" were so numerous and held significant aggregate wealth, they should enjoy the privileges of British subjects (Baker 1910, 158). Baker argued this could be realized through the election of their "own representatives" so as to bring a "political existence" to the majority of the population. The petition concludes that such a request would not break the supposed fealty the colonized have for existing 
institutions. On the contrary, it would bolster their loyalty to the Crown. It would bring British political values in unison with her colonial possessions (158-59).

A more pronounced appeal to local channels of authority was made in the French version of the petition. Ollier $(1910 \mathrm{~g}, 160)$ demanded that Governor William Gromm authorize non-whites to sit on the Legislative Council, thereby enabling a more inclusive "elective representation." Again, the appeal to the nascent democratic machinery as a basis for legitimizing sovereignty was not staged as an antagonistic confrontation. If representation, which Ollier (1910g, 160) claimed "all British subjects have received," were extended to non-whites it would fulfil an English mission of guiding others in "paths of freedom." On 18 April 1844, Ollier (1910d, 328) argued the British "constitution" is "the most beautiful thing in the world," while qualifying this statement with: "[it] is not observed in Mauritius, even though the English occupy the highest echelons!" Heaping praise on British liberties and Common Law, while asserting a contradiction with colonial practice, led him to speculate that if "noble England was as liberal to Mauritius as it was in its headquarters ... [then] it will find children here as devoted as it can count in its midst” (329).

Ollier's promise of duty-bound subjects, who do not carry ulterior motives, flows from the objectives of La Sentinelle. His mission statement is explicit in uprooting "vice and wickedness" in all segments of the population without having "a calculated egoism. Duty and truth will be the only goal" (Ollier 1910i, 154). The conjoined veneration of the British and supplication for accountability was a running motif till the end of his short-lived career. Ollier's ethos conveyed what we might term, following Gorman (2006, 19), "loyalism": pledging allegiance to the Crown so as to provide a source of authority beyond the de facto inequities of colonial laws and customs.

Inducing colonized identification with the colonizer is partial; "to be anglicized is emphatically not to be English" (Bhabha 1994, 87). The colonial desire to produce emulative subjects that exemplify and validate the moral legitimations of British rule (e.g. civilizing missions) depends on constituting insurmountable differences (e.g. race). Ollier's demand for political unity across British possessions authorizes this ambivalent structure of colonial authority. However, the generation of colonial facsimiles can produce incalculable subjects whose mimesis can threaten that very authority (Bhabha 1994, 91). As Ollier chastises the arbitrariness of British rule, which he claims professes liberty but delivers the opposite, a demand to resolve this contradiction can unintentionally undermine the British imaginary he cherishes. The simultaneous affirmation and usurpation of British rule was succinctly captured on 3 June 1843, when Ollier argued "we are the equal of whites at heart and in intelligence, and if we were not the equal of whites by education and standards (morals, manners), tomorrow we shall sacrifice 
everything to acquire their education and morals" (Ollier 1910e, 262, emphasis added).

Documenting Ollier's mimicry goes beyond enriching dominant accounts of his struggle (outlined in the previous section). His loyalism depended upon the mimic's fantasy of a prior unitary British subject as an object of attainment. Ollier failed to recognize the fractured constitution of subjecthood within the British Isles and, following from this, he considered granting rights to the colony simply an extension of a British subject to another geopolitical region. Citizenship in early nineteenth-century Britain (although a term not widely adopted in the lexicon of the period) can trace its modern institutional emergence through the 1832 Reform Act. This Act was central in defining the citizen as an "independent man," an enfranchised adult middle-class tax-paying male who had not been a recent claimant of poor relief (Roberts 2009, 13). The creation of a limited citizenry in Britain did not result in a society of citizens and non-citizens demarcated solely by class and gender. The nascent rights-bearing British subject (i.e. the citizen) informed, and was informed by, colonial domination through the exclusion of racialized others considered unfit to govern themselves (Tabili 2006).

Imperial citizenship did not exist in advance of its claim. It lacked codification as an official status that guaranteed political and civil rights for all subjects. Sukanya Banerjee's (2010, 15-16) study of late Victorian imperial citizenship notes it to be a process of "becoming," indicating a continuous demand as opposed to an achieved status. As a narrative device for redressing its formal absence, one of the central strategies for performing imperial citizenship was an appeal to aspects of modern rational - legal authority. Consider the case of Cornelia Sarobji, an Indian lawyer who drew upon her credentials (gained in Britain) to legitimate her demand to practice in British India. Her plea for non-discrimination was grounded upon a claim to professionalism and expertise that redevized citizenship apart from its gendered and racialized exclusions (Banerjee 2010, 126-27). How Ollier couched his demands through imperial obedience and productivity might appear to exhibit a similar way of depersonalizing rights, creating what Banerjee $(2010,119)$ notes as an approximation to the "formless equality of liberal citizenship." However, as we shall see, Ollier's expression of imperial citizenship was also explicitly coded along racial lines.

Ollier's demand for political representation was inseparable from his desire to show the middle-class respectability of the gens de couleur - "we have our planters, proprietors, our capitalists, traders and merchants" (Ollier, citied in Mulloo 1968, 29). The political crypsis that faithfully reproduces the existing figure of the independent man (via La Sentinelle's formal and informal petitioning) is a moment of acting as if one were a citizen. Though he may intentionally posit semblance, a prior figure of the middle-class non-white colonial citizen in the British Empire is not the object of transplanted repetition. To 
examine how imperial citizenship was uniquely generated, we can turn to his declaration: "we are no longer a conquered people, we are English" (Ollier 1910d, 329). Ollier's claim to speak as, and on behalf of, the gens de couleur imagined a citizenry in Mauritius that was inclusive of non-white subjects. It might appear that his assertion and demand for imperial citizenship "we are English" - both deterritorialized and deracialized citizenship via its applicability across the empire. However, the "we" did not preexist his struggle and did not signify the emptying of English from carrying racial connotations. Race was positioned as inconsequential for equality. Ollier (1910e, 262) proclaimed "we do not want to whiten ourselves ... we are the equals of whites by right ... But the colour of our skin? But origin? What foolishness!” His preservation of race was also deployed as a symbol of equality. This became apparent as he reflected on the everyday workings of La Sentinelle:

The union of white, mulatto and black, it never was more honest, more sincere than in La Sentinelle. White, brown and black hands were in tight brotherhood in our office; they collaborated to write La Sentinelle in my absence, and this is the triumph of the cause of my fellow citizens! It is one of the triumphs of the newspaper whose cause is entrusted to me! (Ollier, cited in Cabon 1963, 155)

Ollier naturalized race as a private trait that should have no significance in social and political life at the same time as he considered it exemplary of anti-racist equality. Describing La Sentinelle as a microcosm of a public in Mauritius situates the multiracial as both model for, and testimony of, equality. The assertion of multiracial harmony creates the pursuit for equality as immanent via the bodies doing the work of equality. Whether one judges this instance of racial cooperation to mark a lack of (post-)racial justice, acting as if one were representative of a multiracial citizenry brought forth a unique manner of claiming to overcome racial hierarchies.

\section{Multiracialism and orientalism}

Mauritius was one of the first Crown Colonies to experiment with indentured labour from India. After abolition, the island became host to more contractbound workers and exported more sugar than any other British possession (Allen 2003). Unlike during the late eighteenth century, when a paternalistic orientalism was juxtaposed to an arbitrary colonial despotism (Nahaboo 2012), by the mid-nineteenth century, orientalism became increasingly geared towards denigrating others along a singular continuum of civilizational worth (Chakrabarty 2000). In the case of Mauritius, the civilizing mission was interlaced with concerns around labour productiveness. The Rawson Committee of 1845 held that indentured workers have a "propensity toward idleness, thievery, petty commerce, and financial irresponsibility" 
(Allen 2003, 59). As the causes of these (perceived) issues were framed in terms of racial/cultural culpability (as opposed to being generated from the plantocracy), measures for redress included withholding wages, forced labour for breach of contract, recruitment deception, civilizing through the Christian mission, and movement restrictions (Pineo 1984; Sundararajan 2006; Tinker 1974).

Mauritius has never had a population that constituted itself as indigenous (Vaughan 2005, 2). Planters, indentured labourers, administrators, exslaves, and traders had more or less interest in naturalizing themselves on the island (Carter and Kwong 1998). Nevertheless, from French rule through to the present, concerns about the origins and "authenticity" of various groups intensified rather than diminished as resources for claiming belonging to Mauritius (Vaughan 2005,2). Following on from the previous section, it might appear that Ollier championed rights for all inhabitants of Mauritius; he did not bind the territory of the island to a racially exclusive people. Working against the grain of hierarchically organizing who could claim belonging to Mauritius, he lamented the situation where "a foreigner, to whichever nation he may belong, is subject to severe hurdles before he is granted naturalization" (Ollier 1910a, 211). However, Ollier's racializing formation of the citizen did not extend to the newly arrived indentured labourers.

Contrary to the overwhelmingly positive representations of Ollier, Mulloo $(1968,30)$ notes he did "nothing to defend the dignity and rights of the Indian labourers." Ollier considered them "aliens" whose only function was to fulfil labour demands (29). He opposed the importation of indentured labour and newly arrived traders by mirroring orientalist representations. Ollier (1910b, 247) found "the Indian, in a condition of perpetual vagrancy, the Chinese, of incessant plundering ... the livery of the Orient is everywhere! ... Everywhere the Indian gets drunk and pillages, the Chinese exploits the country and settles." Here the target becomes immigrants who seek livelihoods outside the plantation economy. One source of purported vagabondage is traced to the "Malabar Camp" where shops become overcrowded residences for undocumented friends of the owners (Ollier 1910c, 224). These locales are said to be staging grounds for thefts outside the bazaar. To curb the sheltering of thieves, Ollier (224) advised colonial authorities to raid "Malabar" shops and apprehend those who "have no right of residence."

Orientalism could be subjected to critical appropriation by those who do not see themselves, or are not seen as, western (Gill 2010). It is a historically dynamic practice that at times failed to sustain domination in congruence with a consistently white colonizing population (Heehs 2003). Orientalism could deviate from uniform political trajectories, as classically outlined by Said (2003). This does not suggest neutrality. Rather, orientalism can be a politically mobile form of racializing essentialism that is imbricated in citizenship claims. Jun (2011) illustrates this through her study of how African Americans 
in the nineteenth century constituted themselves as the true expressers of modernity and citizenship by utilizing orientalist tropes to denigrate Chinese migrants. Ollier's orientalism adopted a similar guise once we focus on how his exclusionary prescription for indentured labourers emerged in concert with his multiracial conception of Mauritius. To grasp how his entwined defense and challenge to the multiracial exceeded imperial labour interests, we can turn to his representation of black ex-slaves.

As the source of planation labour was gradually replenished through indentured workers, the amount of free, yet impoverished, ex-slaves working on small estates or as gardeners grew (Chan Low and Reddi 2000, 230). From the 1820s onwards, the gens de couleur tried to ensure black ex-slaves were not coerced back onto the sugar plantations (Allen 2003, 80). By the 1830s, the gens de couleur's modest acquisition of diversified land and variation in occupation showed alternative economic horizons to the newly emancipated (79-104). However, the hope of a diversified livelihood faded as the majority of ex-slaves faced job insecurity and poverty to the point of constituting a new "underclass" (Chan Low and Reddi 2000, 230). This dire situation was compounded by the enduring monocultural focus on sugar production in the Mauritian economy, lack of political enfranchisement, and the dominance of a Catholic Church that explicitly racialized its black congregation (230-32).

Ollier distanced himself from ex-slaves who were identified as black. As "typical" of the gens de couleur, Ollier sought to maintain distinctions between mulatto and black (Truth and Justice Commission 2011, 247). Maintaining these divisions can be understood as part of the gens de couleur's attempt racially to ring-fence class positions (Arno and Orian 1986). However, unlike his disdain for Indian workers, Ollier did not problematize the presence of black ex-slaves on the island. On the contrary, he argued Indian immigration would show that it is to the newly emancipated "that we must return. That population is cleaner, more diligent, more hardworking" (Ollier 1910f, 355). To ensure the profitability of the sugar industry is maintained, Ollier advises that Mauritius must also "return" to immigration from Africa due to the "good results" obtained in Jamaica (Ollier, citied in Cabon 1963, 127). Acting as if he were a citizen diverges from the socioeconomic direction of colonial authority. His orientalist animosity towards the very presence of the Indian population, and recommendation that black exslaves continue plantation labour, conflicted with the post-abolition project of cheap labour importation from India.

Racial difference is generated, worked on, and perpetually achieved to shape normalized calculable subjects for disciplinary subjection (Ehlers 2012, 139). At times, labouring upon race can usher processes of subjectivation that disassembles its anticipated effects (e.g. racism) (139). Each coupling of race and rights discussed thus far shares these performative dimensions of 
race. How Ollier mobilizes race varies considerably and aspects of his struggle intersect without arriving at a coherent political agenda. His transmission of multiracialism was intrinsic to how he acted as if he were a loyal citizen and an orientalizing subject. Taken together, Ollier carves a unique racialist expression of one of citizenship's enduring prerogatives: inclusion and exclusion.

The moment of struggling is what lifts the colonized from their immobilization as ahistorical subjects (Fanon 2004). History for non-white colonized subjects is often viewed as impossible to realize when acquiescing to British rule. The dominance of this perspective can be partially attributed to the success of postcolonial nationalist movements in highlighting how racial hierarchies were intrinsic to imperial rule; expelling the British was the only option (Mehta 2011). Rémy Ollier's claim to imperial citizenship might therefore appear as testimony to a regressive past. However, his intervention carries political significance for postcolonial national narration. It reveals the contingency of national self-determination as the site and scale for colonial racialized subjects to develop rights claims.

Ollier's struggle does not exemplify a historical subject who plots citizenship as a rupture from imperial rule. His struggle points to another constitutive moment of political agency within the British Empire by creating citizenship under conditions of domination. In this seemingly paradoxical situation, it is important to consider citizenship as an act. Ollier acted as if he were a citizen, standing in for a public to write new scripts of what it meant to be a citizen in Mauritius. This is not a generic intervention that finds articulation across postcolonial mobilizations during the twentieth century. Regardless of his intentions or success, Ollier both demanded and enacted a novel multiracial citizenry through La Sentinelle in ways that inaugurated a subversive (and at times orientalist) loyalism in Mauritius.

If Ollier were alive today, he might be encouraged and dismayed in equal measure to find that his statue occupies the same site as Adrien d'Épinany (1794-39), pioneer of the Mauritian free press and consolidator of French representation in colonial affairs. Ollier's multiracial articulation of imperial citizenship unsettled the prevailing conditions that saw journalistic enterprise and civic associations as the preserve of white colonizers. He might therefore be more enthused to find his memorialization alongside that of Manilal Doctor $(1881-56)$, who sought to combat the maltreatment of the colonized via offering representation in the courtroom. But unlike Doctor, who was particularly receptive to indentured labourers' grievances, Ollier viewed the surge 
in post-abolition immigration as a threat to the established non-white populations.

As we pass the bicentenary of Ollier's birth, it is important to reflect on how and why his activism should be remembered. His political ambiguity cannot be resolved by situating it within a cumulative narrative of progress, located between imperial domination and a more inclusive form of anticolonial activism. Equally, his memorialization does not simply bolster the litany of figures that are preserved through Mauritian history. I have argued Ollier's campaign indicates a more complex relationship with citizenship in Mauritius than currently appreciated. Facets of his struggle unsettle the notion of citizenship unfolding in a singular direction with a uniform objective. Canvassing the vicissitudes of his struggle exemplifies citizenship as a historically discontinuous political project, always "unfinished" and "unfinishable" (Balibar 2004, 190).

\section{AQ2 References}

Allen, Richard B. 2003. Slaves, Freedmen, and Indentured Laborers in Colonial Mauritius. Cambridge: Cambridge University Press.

Arno, Toni, and Claude Orian. 1986. L'île Maurice, une société multiraciale. Paris: L'Harmattan.

Baker, Edward. 1910. "Petition a a Reine [Texte Angalis], 1843." In Rémy Ollier. Sa vie et son oeuvre. Jugement de la posterité, edited by J. O. Bijoux, 158-159. Port Louis: Nouvelle Imprimerie Cooperative.

Balibar, Etienne. 2004. We, the People of Europe. Princeton: Princeton University Press.

Banerjee, Sukanya. 2010. Becoming Imperial Citizens: Indians in the Late-Victorian Empire. Durham, NC: Duke University Press.

Barker, Anthony J. 1996. Slavery and Antislavery in Mauritius, 1810-33: The Conflict between Economic Expansion and Humanitarian Reform under British Rule. London: Macmillan.

Benoit, Norbert. 1995. "Un Certain Rémy Ollier, Fils d'une Ancienne Esclave." In Memorial Remy Ollier: 150e anniversaire de la mort de Rémy Ollier 1845-1995, edited by Jean-Georges Prosper, 3539. Moka: Mahatma Gandhi Institute.

Beverley, John. 1999. Subalternity and Representation: Arguments in Cultural Theory. Durham, NC: Duke University Press.

Bhabha, Homi K. 1994. The Location of Culture. London: Routledge.

Bhambra, Gurminder K. 2015. "Citizens and Others: The Constitution of Citizenship through Exclusion.”
Alternatives: Global, Local, Political 40 (2): 102114. doi:10.1177/0304375415590911.

Bijoux, J. O. 1910. Rémy Ollier. Sa vie et son oeuvre. Jugement de la postérité. Port Louis: Nouvelle Imprimerie Cooperative.

Bijoux, J. O. 1917. Le Centenaire de Rémy Ollier: 1816-1916. Port Louis: General Printing and Stationery.

Bissoondoyal, Basdeo. 1968. The Truth about Mauritius. Bombay: Bharatiya Vidya Bhavan.

Bush, Barbara. 2006. Imperialism and Postcolonialism. Harlow: Longman.

Cabon, Marcel. 1963. Rémy Ollier. Port Louis: Editions Mauriciennes.

Carter, Marina, and James Ng Foong Kwong. 1998. "Creoles and Immigrants in the 19th Century: Competition and Cooperation in Mauritius." In Colouring the Rainbow: Mauritian Society in the Making, edited by Marina Carter, 41-60. Port Louis: CRIOS.

Chakrabarty, Dipesh. 2000. Provincializing Europe: Postcolonial Thought and Historical Difference. Princeton: Princeton University Press.

Chan Low, Jocelyn, and Sadasivan Reddi. 2000. "Malaise Creole: Towards a New Ethnic Identity?" In Towards the Making of a Multi-Cultural Society, edited by Sooryakanti Nirsimloo-Gayan, 228-237. Moka: Mahatma Gandhi Institute.

Chatterjee, Partha. 1986. Nationalist Thought and the Colonial World: A Derivative Discourse. London: Zed Books.

AQ4 
Chatterjee, Partha. 2004. The Politics of the Governed: Reflections on Popular Politics in Most of the World. New York: Columbia University Press.

Chatterjee, Partha. 2010. "Reflections on "Can the Subaltern Speak?' Subaltern Studies after Spivak.” In Can the Subaltern Speak? Reflections on the History of an Idea, edited by R. C. Morris, 81-86. New York: Columbia University Press.

Colville, Charles. 1830. "Despatch from Governor Colville, 1 Oct 1830." Colonial Office, National Archives (CO 714/95).

Ehlers, Nadine. 2012. Racial Imperatives: Discipline, Performativity, and Struggles Against Subjection. Bloomington: Indiana University Press.

Fanon, Frantz. 2004. The Wretched of the Earth. New York: Grove Press.

Fokeer, A. F. 1917. A Biographical Sketch of the Life, Work and Character of Rémy Ollier. London: General Printing and Stationery.

Furlong, Robert. 2005. "Préhistoire, Émergence, Évolution d'une Littérature: Le Cas du XIXe Siècle Mauricien." Francofonia 48: 13-39. http://www.jstor.org/ stable/43016310.

Gill, Jagvinder. 2010. "Re-Oriented Britain - How British Asian Travellers and Settlers have Utilised and Reversed Orientalist Discourse 1770-2010." $\mathrm{PhD}$ diss., University of Warwick.

Gorman, Daniel. 2006. Imperial Citizenship: Empire and the Question of Belonging. Manchester: Manchester University Press.

Green, William A. 1991. British Slave Emancipation: The Sugar Colonies and the Great Experiment 1830-1865. Oxford: Oxford University Press.

Guha, Ranajit. 1982. "On Some Aspects of the Historiography of Colonial India." In Subaltern Studies I: Writings on South Asian History and Society, edited by Ranajit Guha, 1-8. Delhi: Oxford University Press.

Harmon, Jimmy. 2015. "Sant Nelson Mandela Pou Kiltir Afriken ek Kreol - Rémy Ollier (1816-1845): Enn Lavi, Enn Konba." Le Mauricien. http://www. lemauricien.com/article/sant-nelson-mandela-poukiltir-afriken-ek-kreol-remy-ollier-1816-1845-ennlavi-enn-konba.

Heehs, Peter. 2003. "Shades of Orientalism: Paradoxes and Problems in Indian Historiography." History and Theory 42 (2): 169-195. doi:10.1111/14682303.00238 .

Isin, Engin F. 2002. Being Political: Genealogies of Citizenship. Minneapolis: University of Minnesota Press.

Isin, Engin F. 2012. Citizens without Frontiers. London: Bloomsbury.

Jun, Helen. 2011. Race for Citizenship: Black Orientalism and Asian Uplift from Pre-Emancipation to
Neoliberal America. New York: New York University Press.

Li, Victor. 2009. "Necroidealism, or the Subaltern's Sacrifical Death." Interventions: International Journal of Postcolonial Studies 11 (3): 275-292. doi:10.1080/13698010903255478.

Macmillan, Allister. 2000. Mauritius Illustrated: Historical and Descriptive, Commercial and Industrial. New Delhi: Asian Educational Services.

Mantena, Karuna. 2016. "Popular Sovereignty and Anti-Colonialism." In Popular Sovereignty in Historical Perspective, edited by Richard Bourke and Quentin Skinner, 297-319. Cambridge: Cambridge University Press.

Martial, Yvan. 1995. "Rémy Ollier, Un Libérateur pour les Mauriciens d'Aujourd'hui." In Memorial Rémy Ollier: 150e anniversaire de la mort de Rémy Ollier 1845-1995, edited by Jean-Georges Prosper, 1924. Moka: Mahatma Gandhi Institute.

Mathur, Hansraj. 1991. Parliament in Mauritius. RoseHill: Editions Fr L'Ocean Indien.

Mehta, Pratap Bhanu. 2011. "After Colonialism: The Impossibility of Self-Determination." In Colonialism and Its Legacies, edited by Jacob T. Levy and Iris Marion Young, 147-170. Plymouth, NH: Lexington.

Mulloo, Anand S. 1968. Footprints. Port Louis: Standard Printing.

Mulloo, Anand S. 2007. Voices of the Indian Diaspora. Delhi: Motilal Banarsidass.

Nahaboo, Zaki. 2012. "Subverting Orientalism: Political Subjectivity in Edmund Burke's India and Liberal Multiculturalism." Citizenship Studies 16 (5-6): 587-603. doi:10.1080/13621025.2012.698483.

Napal, Dayachand. 1984. British Mauritius 18101948. Moka: Mahatma Gandhi Institute.

Ollier, Rémy. 1910a. "5 Decembre 1843." In Rémy Ollier. Sa vie et son oeuvre. Jugement de la postérité, edited by J. O. Bijoux, 210-211. Port Louis: Nouvelle Imprimerie Cooperative.

Ollier, Rémy. 1910b. “10 Octobre 1844.” In Rémy Ollier. Sa vie et son oeuvre. Jugement de la postérité, edited by J. O. Bijoux, 247. Port Louis: Nouvelle Imprimerie Cooperative.

Ollier, Rémy. 1910c. "24 Fevrier 1844.” In Rémy Ollier. Sa vie et son oeuvre. Jugement de la postérité, edited by J. O. Bijoux, 223-224. Port Louis: Nouvelle Imprimerie Cooperative.

Ollier, Rémy. 1910d. "Dures Vérités, 18 Avril 1844." In Rémy Ollier. Sa vie et son oeuvre. Jugement de la postérité, edited by J. O. Bijoux, 325-330. Port Louis: Nouvelle Imprimerie Cooperative.

Ollier, Rémy. 1910e. "La Population de Couleur, 3 Juin 1843." In Rémy Ollier. Sa vie et son oeuvre. 
Jugement de la postérité, edited by J. O. Bijoux, 260266. Port Louis: Nouvelle Imprimerie Cooperative.

Ollier, Rémy. 1910f. "Le Petite Culture, 19 Octobre 1843.” In Rémy Ollier. Sa vie et son oeuvre. Jugement de la postérité, edited by J. O. Bijoux, 353356. Port Louis: Nouvelle Imprimerie Cooperative.

Ollier, Rémy. 1910g. "Petition a la Reine." In Rémy Ollier. Sa vie et son oeuvre. Jugement de la postérité, edited by J. O. Bijoux, 157-160. Port Louis: Nouvelle Imprimerie Cooperative.

Ollier, Rémy. 1910h. "Préjugés, 5 Novembre 1844.” In Rémy Ollier. Sa vie et son oeuvre. Jugement de la postérité, edited by J. O. Bijoux, 369-373. Port Louis: Nouvelle Imprimerie Cooperative.

Ollier, Rémy. 1910i. "Prospectus de 'La Sentinelle', 21 Mars 1843." In Rémy Ollier. Sa vie et son oeuvre. Jugement de la postérité, edited by J. O. Bijoux, 153-155. Port Louis: Nouvelle Imprimerie Cooperative.

Pandey, Gyanendra. 2010. "Introduction: The Subaltern as Subaltern Citizen." In Subaltern Citizens and their Histories: Investigations from India and the USA, edited by Gyanendra Pandey, 1-12. London: Routledge.

Pineo, Huguette Ly-Tio-Fane. 1984. Lured Away: The Life History of Indian Cane Workers in Mauritius. Moka: Mahatma Gandhi Institute.

Prosper, Jean-Georges. 1995. "Que devons-nous Que doit l'île Maurice à Rémy Ollier?” In Memorial Remy Ollier: 150 e anniversaire de la mort de Rémy Ollier 1845-1995, edited by Jean-Georges Prosper, 16-18. Moka: Mahatma Gandhi Institute.

Raynal, L. Gaëtan. 1995. "Il y a 152 Ans Paraissait le 1er Numero de 'La Sentinelle'." In Memorial Rémy Ollier: 150e anniversaire de la mort de Rémy Ollier, edited by J. Prosper, 62-65. Moka: Mahatma Gandhi Institute.

Report on the Slave Trade. 1828. Colonial Office, National Archives (CO 167/126).

Roberts, Matthew. 2009. Political Movements in Urban England, 1832-1914. Basingstoke: Palgrave Macmillan.

Said, Edward W. 2003. Orientalism. London: Penguin.
Salverda, Tijo. 2015. The Franco-Mauritian Elite: Power and Anxiety in the Face of Change. Oxford: Berghahn.

Spivak, Gayatri Chakravorty. 1988. "Can the Subaltern Speak?" In Marxism and the Interpretation of Culture, edited by C. Nelson and L. Grossberg, 66111. Basingstoke: Macmillan Education.

Spivak, Gayatri Chakravorty. 1999. A Critique of Postcolonial Reason: Toward a History of the Vanishing Present. Cambridge, MA: Harvard University Press.

Spivak, Gayatri Chakravorty. 2005. "Scattered Speculations on the Subaltern and the Popular." Postcolonial Studies: Culture, Politics, Economy 8 (4): 475486. doi:10.1080/13688790500375132.

Spivak, Gayatri Chakravorty. 2010. "In Response: Looking Back, Looking Forward." In Can the Subaltern Speak? edited by R. C. Morris, 227-236. New York: Colombia University Press.

Sundararajan, Saroja. 2006. From Bondage to Deliverance: Indentured Labour in Mauritius and British Guiana. New Delhi: Allied Publishers.

Tabili, Laura. 2006. "A Homogenous Society? Britain's Internal 'Others', 1800-present." In At Home with Empire: Metropolitan Culture and the Imperial World, edited by Catherine Hall and Sonya O. Rose, 53-76. Cambridge: Cambridge University Press.

Teelock, Vijaya. 2001. Mauritian History: From its Beginnings to Modern Times. Moka: Mahatma Gandhi Institute.

Tinker, Hugh. 1974. A New System of Slavery: The Export of Indian Labour Overseas 1830-1920. Oxford: Oxford University Press.

Truth and Justice Commission. 2011. Report of the Truth and Justice Commission: Volume 1. Port Louis: Government Printing,

Vaughan, Megan. 2005. Creating the Creole Island: Slavery in Eighteenth-Century Mauritius. Durham, NC: Duke University Press.

Wesley, Charles H. 1921. "Rémy Ollier, Mauritian Journalist and Patriot." The Journal of Negro History 6 (1): 54-65. doi: 10.2307/2713828. 